\title{
A Report to Show the Prevalence of Schistosomiasis in Kwaita, Kwali Area Council
}

Aisha Ojone $A^{*}$

Buhari Support Organizations, Kleenol, Nigeria

\section{Background}

Urinalysis, malaria parasite test, random blood sugar were conducted for the people of Kwaita, Kwali Area council, diagnoses made and drugs administered. 205 persons benefited from this scheme out of which 30 had malaria, 12 had Schistosomiasis, 1 had river blindness and 150 person's dewormed.14.64\% of the total population had malaria. 5.8 $\%$ of the Population had Schistosomiasis.

Out of the 12 persons infected with Schsitosomiasis, 8 were below the ages of 10-15. This group of boys frequent the river for swimming, accounting for the prevalence of the disease in the community.

\section{Introduction}

Urinalysis, random blood sugar, blood pressure checks, malaria test was conducted for the people of Kwaita on the $7^{\text {th }}$, February 2015 following the report by channels television on high prevalence of Schsitosomiasis and river blindness in Kwaita community, Kwali Area Council.

Schistosomiasis is also known as Bilharzia, snail fever or Katayama fever. It is a disease caused by parasitic worms of the Schistosoma type. Signs and symptoms may include abdominal pain, diarrhea, bloody stool or blood in the urine. Urinalysis is an effective way of investigating Schistosomiasis coupled with urine microscopy to search for the ova of Schistosoma.

This disease is spread by contact with water that contains the parasites. The disease is especially common among children in developing countries as they are more likely to play in infected water. Other high risk group includes farmers, fishermen, and people using infected water for their daily chores.

Schistosoma mansoni and Schistosoma intercalatum causes intestinal Schistosomiaisis. Schistosoma haematobium causes urinary Schistosomiasis.

\section{Methodology}

A preliminary survey was conducted for needs assessment. Prior to the visit by the BSO team to Kwaita community on the $7^{\text {th }}$ of January for the medical outreach, sterile containers were distributed to the populace for their urine samples. Four benches were created at the event, microbiology bench for the conduction of urinalysis, malaria test and random blood sugar, blood pressure and weighing scale bench, pharmaceutical bench and the doctor's bench.

Beneficiaries moved from the microbiological bench and proceeded to the next bench to check their blood pressure and weight before proceeding to the doctors for diagnoses and finally to the pharmaceutical bench for drugs. Multivitamins were given to all present.

\section{Results}

205 persons benefited from the scheme out of which 30 had malaria, 12 suffered from Schistosomiasis and 1 person had river blindness. The result tabulated below (Table 1).

$5.9 \%$ of the total beneficiaries had Schistosomiasis, $14.6 \%$ of the

\begin{tabular}{|c|c|c|c|c|}
\hline $\mathbf{S} / \mathbf{N}$ & $\begin{array}{c}\text { Diseasel } \\
\text { Infection }\end{array}$ & $\begin{array}{c}\text { Total number } \\
\text { diagnosed }\end{array}$ & Drugs used & Remarks \\
\hline 1 & Schistosomiasis & 12 & Praziquantel & $\begin{array}{c}\text { Mostly youths between } \\
\text { the ages of 10-15 }\end{array}$ \\
\hline 2 & Malaria & 30 & ACT & $\begin{array}{c}\text { Mostly children below } \\
\text { the ages of 5-10 }\end{array}$ \\
\hline 3 & River blindness & 1 & Zentel & Mostly aged \\
\hline 4 & $\begin{array}{c}\text { High blood } \\
\text { pressure }\end{array}$ & 20 & Referals & \\
\hline 5 & UTI & 3 & & \\
\hline 6 & Diabetes & 0 & & \\
\hline
\end{tabular}

Table 1: Free medical outreach to kwaita, kwali area council.

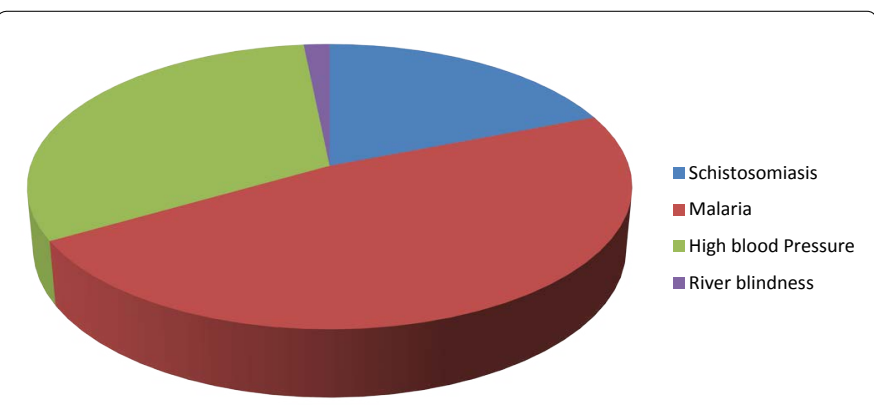

Figure 1: Graphical representation of the prevalence of diseases in Kwaita.

beneficiaries had malaria, $0.5 \%$ of the beneficiaries were treated for river blindness, $9.8 \%$ of the total beneficiaries had high blood pressure (Figure 1).

\section{Conclusion}

There is an urgent need for follow up on cases of Schistosomiasis to effectively reduce its prevalence. Moreso, a functional clinic is essential in the community to curb the spread of diseases and further improve the general livelihood of the People.

*Corresponding author: Aisha Ojone A, Buhari Support Organizations, Kleenol, Nigeria, Tel: +23437903795; E-mail: aishaojabu4@gmail.com

Received: October 16, 2017; Accepted: May 24, 2018; Published: May 31, 2018

Citation: Aisha Ojone A (2018)A Report to Show the Prevalence of Schistosomiasis in Kwaita, Kwali Area Council. Prim Health Care 8: 296. doi: 10.4172/21671079.1000296

Copyright: (C) 2018 Aisha Ojone A. This is an open-access article distributed under the terms of the Creative Commons Attribution License, which permits unrestricted use, distribution, and reproduction in any medium, provided the original author and source are credited. 